\title{
Utilizing Mobile Assisted Language Learning (MALL) for Teaching English to Non- Formal Learners in Pakistan
}

\author{
Muhamamd Mooneeb Ali*, Zoobia Asad**, Shagufta Moghal***
}

\begin{abstract}
Non formal education is an important education type that helps the availability and continuity of education where formal schooling is not available. English language learning assumes a significant role in the National Educational program. Despite its importance, English Language learning is a problematic area for learners in the formal and non-formal education systems. This research intends to explore the importance of using mobile assisted language learning (MALL) in non-formal English language environments in Pakistan. The population of this research comes from various institutions all over Punjab, Pakistan, where 60 non - formal learners were chosen through simple random sampling method. The research design was experimental whereas test (pre and post)was used as a tool to collect data. The findings present that MALL created a significant impact on English Language learning of non-formal learners. It further ascertained that MALL can be an attractive and result oriented method in non-formal settings.
\end{abstract}

Keywords: Non-Formal Education, English language learning, Mobile Assisted Language Learning (MALL), Pakistani Education

This Article can be cited as:

Ali M M., Asad Z., Moghal S., (2020). Utilizing Mobile Assisted Language Learning (MALL) for Teaching English to Non- Formal Learners in Pakistan, Journal of Arts and Social Sciences. VII (2), 70-81.

\footnotetext{
* Muhamamd Mooneeb Ali, Department of English, Government College of Science, Wahdat Road, Lahore, Pakistan.

** Zoobia Asad, PhD Scholar, Research and Evaluation Department, Lahore College for Women University, Lahore, Pakistan.

*** Correspondence concerning this article should be addressed to Shagufta Moghal, Department of Professional Studies, Institute of Education Lahore College for Women University, Lahore, Pakistan Shagufta.moghal@lcwu.edu.pk.
} 


\section{Introduction}

Language is a unique characteristic of human brings man. Without the use of language man's progress and civilization would be inconceivable. Language is a universal form of expression present in our thoughts, imagination, prayers, reflections, relations and correspondence. It is a very complex human phenomenon; all endeavors to characterize it have proved to be insufficient. Sapir (1921) stated that language is a way for conveying our needs, emotions and thinking through symbols that are arranged intentionally. In another research Bloch and Trager (1942) stated that language is a vocal process of arbitrary signs develop exchange and cooperation among social groups.

\section{Use of language for Education}

A language is a medium of correspondence in our daily communication amongst family and society. It is vivid that normal communication is not possible without language (Ali et.al, 2020). The significance and importance of the use of language in education cannot be denied. The process of teaching and learning both requires communication which cannot be possible without the use of language. The overall sphere of education is totally dependent upon the use of language (Zedan et al., 2013).

In Pakistan English is taught as $2^{\text {nd }}$ language (Ali et al., 2020). Only $11 \%$ people can speak English (Behraam et al., 2015). The rest of the population takes keen interest in English and it is regarded as a status symbol in Pakistani society. There are a lot of problems and issues that create barriers for the teachers to teach English like lack of facilities in the classroom, sticking to old methods, focusing of conventionalism and working to get results rather than achieving skills for learners. (Ali et al., 2020)

\section{Non Formal Education}

Any kind of education that is created beyond formality and formal setup is called non formal education. In non-formal education, an individual can work independently to play a pivotal role to develop learning in conditions where the facilities are not readily available (Moayedi \& Azizi, 2011). Non formal education is deliberate, intentional and methodical type of education which occurs outside formal settings of schools and classrooms. Here the method of instructions, syllabus and curriculum are devised to provide utmost convenience to the learners. The major objective of this type of education is to attain maximum learning. Therefore, it emphasizes on learners more in contrast with formal education (Etling, 1993).

This educational type assumes a particular learning challenge and role for the individual. As an Islamic country, Pakistan follows the Islamic ideology and the first non-formal educator is the beloved Holy Prophet Muhammad (صلى بلا علىه وآله وسلم) who was a leader and thought leader for educationists all over the world.

\section{Non-formal Education in Pakistan}

Rogers (2005) stated that non formal education started in the 1950s where the less developed countries actually tried to address issues of their education. The biggest issues were to educate people in deprived areas where there were no formal schools. These circumstances gave way to non-formal education. (Kedrayate, 2012).

Bajwa et al., (2011) stated that non-Formal Schools (NFS) were introduced in 1996 in Pakistan. The concept of non-formal schools was centered on linking community, parents and other relations of society to promote education. It was also structured to entice those learners who had dropped out or had 
left because of various reasons and had to resume education after a gap (Jumani, Rahman \& Bib. 2011). The communities provided room for studying and officially arranged salary for teacher. These non- formal schools had opened in those far off areas where there was no access of education. (Gujjar, Naoreen\& Aslam, 2010).

The literacy rate of Pakistan is $70 \%$ in 2020 (Baloch et al., 2020). The literacy rate is much lesser in villages due to there is no any single primary school nearby. Villagers do not sent their girls for education in far off schools. The literacy rate in urban areas is more than $80 \%$ and $30 \%$ plus in rural areas of Punjab (Rehman, Jingdong \& Hussain, 2015).There have been studies which have highlighted the problems faced in these circumstances, particularly as far as enormous students' quality per class, poor ambiance and demotivated teachers are concerned.

\section{Mobile Assisted Language Learning}

Mobile assisted language learning or MALL can be taken as the utilization of portable devices like tables, handheld devices and mobile phones etc. in language learning processes (Ali, Malik \& Rehman, 2016). This concept is a regular feature in western institutions. The classrooms are equipped with MALL technology and it has given alot of advantages for language learning. Despite its utility, it is not a commonly used phenomenon in under developed countries. This technological method has created a revolution in language learning and the learners have deeply attracted to this method. The reason may be that MALL technology is lower in cost, flexible, smaller in size and easy to handle, it is user convenient and permit ubiquity in learning (Ali, Malik \& Anwar, 2018).It attracts new users because of innovative and interesting methods of learning. MALL is one of the least used methods in Pakistani educational context until the recent COVID-19 pandemic. Yet MALL can be well suited to the local context as it only needs internet access that permits to learn in informal setting as well. The user can learn at ones convenience and will outside the boundaries of formal face-to-face classrooms.

\section{Problem Statement of this study}

Non-formal learning is a strenuous task, especially in Pakistan as the formal teachers are used to conventional techniques to teach English. Hence, the non-formal teachers who are less trained in remote or online teaching modes actually follow the same conventional ways of teaching English which are prevailing since decades in traditional classrooms. Therefore, learners face a lot of difficulty in learning English, ultimately losing their interest in English language learning and some discontinue their education.

\section{Research Significance}

This research focuses upon implanting MALL in English language classrooms of grade 4 learners of in non-formal classrooms. This research is a benchmark experiment because if it becomes successful it will overhaul and transform the system of non-formal education and it will provide a way-out to teach learners with impact and maximum output. It will also eliminate the hindrances of non-formal learners in learning English and will uplift learners at all levels to overcome their English language learning problems.

\section{Research Hypothesis}

The researcher proposes the following hypothesis for the experimental study:

- MALL improves the English language learning of non-formal grade 5 learners in the Pakistani context 


\section{Research Question}

The principal research question for this study is as follows:

- Does MALL help and improve English language learning for non-formal grade 5 learners in the Pakistani context?

\section{Review of Literature}

Non formal education is a form that promotes experimental and experiential activities for learning that aids to develop knowledge and skill. Non-formal learning actually develops confidence and motivation in learners. Its objectives are to engage learners into the learning process(Harris\&Wihak, 2018).

Initiated in 1921 after the revolution in Mexico it was an arrangement to initiate learning to engage learners in a positive manner to make them educated (Gochicos, 1993).In the late of 1960s and 1970s non formal education became a part of worldwide education. It can be viewed as an off-shoot of methods for deep rooted learning(Tight, 1996).

Fordham(1979) proposed that in the 1970s, four qualities were related with non-formal education, as follows: importance with respect to the needs of target groups, importance with the kind/type of person, clearly articulated purposes for education, and adaptability in the selection of teaching/learning techniques.

\section{Advantages of Non-formal educational contexts}

Non formal education is a mode to develop essential skills and competencies in the learners. It also helps the learners to show commitment, involvement and responsibility in the learning process (Linden, 2015). Non formal education is advantageous as it give confidence to the learners to take initiative in their own learning. It also aids in developing intercultural awareness, self-worth and personal esteem, selfrespect, self-management and motivation, creativity and confidence (Belle, 1982). Intellectually, students learn and gain practice in taking initiative, collaboration, cooperation, problem- solving, communication skills and administrative skills (Guilherme \& Morgan, 2009). There is a lot of flexibility and many available resources within the non-formal education to engage learners in activities outside the school context (Vartolome, 2017).

\section{English in non-formal educational contexts}

Instructing young learners is an arduous task. According to Harmer (2013), "our job must be to provoke student engagement with material which is relevant and involving", through designing activities according to student's interest. Foster (2011) was of the view that the different segments and clusters within society may collaborate and work together in order to improve education in the formal and non- formal contexts. He also stressed that knowledge communities must be setup to promote learning in deprived communities, such as the remote areas of Pakistan.

The non-formal sector in Pakistan is an area which has not been explored or planned for properly. The policy makers do not have the complete information about the exact number of students engaged, the teaching materials used, the challenges in the process and the hindrances faced by teachers and learners. It is also not known what problems teachers face when teaching the Punjab Textbooks in such scenarios and environments. Hence, there is no support or help for the educators in such classrooms. Providing assistance to such educators may result in boosting the way English may be acquired by learners in non-formal settings towards developing bilingualism as a nation. It has been highlighted in research that the 
acquisition of a language in early years not only helps acquire proficiency but also contributes to cognitive development if the correct approaches are used (Vilke, 1977).

\section{Research trends on non-formal Education}

Internationally, there are a lot of researches on non-formal education. Gloria et al., (2014) presented the results of a study which showed that practical activities helped develop skills and learning of local learners in middle school levels through non formal education. A study performed by Shohel \& Howes (2018) was on the change of learning style from formal to non-formal and to explore their differences. Through interviews it was discovered that there were contrastive differences between the two modes of education which affected the learners. Norqvist \& Leffler (2017) reported results of another study which explored and highlighted that though it is difficult to view segregation between formal and non-formal education, yet non-formal education is a method of impactful and effective for learners.

\section{Past researches on MALL}

Azli, Shah and Mohamad (2018) investigated the perception on the usage of MALL in English as a Second Language (ESL) among private vocational college students. Data were collected through a survey questionnaire adapted from Technology Acceptance Model (TAM). The results revealed that respondents had positive perception on the usage of MALL. Majority of the respondents showed overall agreement on both constructs perceived usefulness (PU) and perceived ease of use (PEoU) of MALL. They believed the usage of MALL will enhance the teaching and learning process. Nino (2014) conducted a perceptionbased study on 286 university students. The study aimed at finding the use of mobile applications for independent language learning in higher education. It also attempted to know how learners use mobile apps in line with their class to enhance their learning experience. The study used survey design. The analyzed data suggested that MALL is suitable for passive language skills such as vocabulary acquisition, written and oral comprehension, pronunciation, vocabulary and grammar practice in particular. The responses of the students also highlighted the advantages of the use of mobile apps for language learning which include convenience, use of authentic resources, offer immediate feedback and several opportunities to personalize authentic language practice. Dehkordi and Taki (2018) have recently investigated the perception of 90 Iranian EFL learners toward the use of mobile-assisted language learning. The objective of the study was to highlight the difference between the mobile learning perceptions of Iranian male and female EFL learners. It also attempted to know the difference between the mobile learning adequacies of Iranian male and female EFL learners. In order to meet the objectives, 90 male and female EFL learners of different proficiency levels were selected as sample of the study. The instrument utilized in the study was Mobile Learning Perception Scale developed by Uzunboylu and Ozdamli (2011). Two independent T tests were performed to determine the difference between male and female participants. The results claimed that although, the perception of male learners was slightly more than more than female learners, it failed to be statistically significant. Therefore, there is no significant difference between Iranian male and female learners' mobile learning perception and first null hypothesis was accepted. So was the case with second hypothesis which was related to adequacy of mobile learning perception. However, both male and female learners had a positive view towards e-learning and technology-based language learning. Another study about perception of MALL was done by Oz (2014).

\section{Recent researches on MALL in Pakistan}

Ali et al., (2020) performed a study to explore the impact of MALL on ESL learners' vocabulary development through experimental design; they proved that MALL is effective and impactful method as compared with other methods. It also showed that MALL improves vocabulary learning in ESL situations .Ali et al., (2019) also conducted a research which focused on the beliefs and perceptions of 
formal ESL learners with respect to MALL. The study concluded that MALL is a welcome change for Pakistani learners and can be implemented in local learning contexts as Pakistani learners appreciated this learning innovation.

Ali, Gulzar and Anwar (2018) investigate the application and usage of MALL in grammar teaching and developing grammatical understanding. The study was experimental in nature. By the performance of the two groups the results showed that MALL creates positive results on the learners grammatical knowledge.Likewise, Ali, Malik and Rehman (2016) explored through a survey and found out that MALL is highly appreciated and received by Pakistani learners. Through a questions were asked from the participants of the research and it was found out that MALL has been a new wave of technology for local students.

These above studies concluded the fact that MALL is getting popular in Pakistani educational contexts. There are instances of researches and experiments being performed to utilize MALL in educational settings. Surprisingly there is no research on applying MALL in non-formal educational context. Eyeing to the need and situations of learning MALL can be a perfect tool in non-formal situation. Therefore sensitizing to this research gap the researchers will attempt to apply MALL in non-formal educational settings. This research will be novel as it will provide a new wave in non-formal education.

\section{Research Methodology}

This exploration is quantitative in nature. The researcher selected 120 learners from grade 4 randomly. There was no gender consciousness or segregation for the study as both were included for the research. The learners were divided into two groups. One group named as controlled was taught through already established methods in non-formal educational settings. The other group i.e. the experimental learnt by applying MALL in their respective English language learning situations. A pretest was initially performed to evaluate learners about their already existed knowledge. The contents of pre-test were identical for both groups. Furthermore, after pre-test the groups were segregated into controlled and on the other hand experimental. Both groups were instructed for two weeks and each day the duration of instruction was 45 minutes. After the teaching procedure a post -test was conducted and results of controlled and experimental groups were compared to evaluate their performances. For obtaining data an independent sample $t$ test was applied using SPSS (23). The following results of both the groups are presented in separate tables.

\section{Delimitations of Research}

This research is delimited to the Punjab region in Pakistan only. The researcher focused on a small group of learners; through simple random sampling technique only 120 learners were selected. Moreover, only grade 4 learners were selected to have better results.

\section{Results Pretest Results}

In Table 1, there are two sample groups; control group (x1) and experimental group (x2) each with sample size of $n=60$. Pretest results reveal that sample mean value $m 1=9.18$ of the control group is slightly less than the sample mean value $\mathrm{m} 2=9.85$ of experimental group.

Table 1. Independent Sample T test (Controlled and Experimental Group) 


\begin{tabular}{|c|c|c|c|c|}
\hline Pretest & $\mathbf{N}$ & Mean & Std. Deviation & Std. Error Mean \\
\hline Experimental Group (x2) & 60 & 9.85 & 1.287 & .166 \\
\hline Control Group (x1) & 60 & 9.18 & 1.282 & .166 \\
\hline
\end{tabular}

The extent of sample data spread was measured by standard deviation (SD), which was represented by $\mathrm{s} 1=1.282$ for control group, and was slightly less than SD of experimental group $\mathrm{s} 2=$ 1.287. The estimated standard errors show the dispersion of sample means $(\mathrm{m} 1, \mathrm{~m} 2)$ about their respective population means $(\mu 1, \mu 2)$; both groups have approximately equal estimated standard errors of sample means, represented by se $1=\operatorname{se} 2=0.166$.

Table 2. Independent Samples Test

\begin{tabular}{|c|c|c|c|c|}
\hline \multirow{2}{*}{ Independent Samples Test } & \multicolumn{2}{|c|}{$\begin{array}{c}\text { Levene's Test for Equality of } \\
\text { Variances }\end{array}$} & \multicolumn{2}{c|}{ t-test for Equality of Means } \\
\cline { 2 - 5 } & F & P-value (Sig.) & T & Df \\
\hline Pretest $\quad \begin{array}{c}\text { Equal variances } \\
\text { assumed } \\
\text { Equal variances not } \\
\text { assumed }\end{array}$ & .494 & .484 & 2.843 & 118 \\
\hline
\end{tabular}

In the Table 2 , the F-test statistic value $(F=0.494)$ with $p$-value $=0.484>(\alpha=0.05$ as level of significance) reveals that Ho is accepted as it may be concluded that two respective populations have equal SD or variances $(\sigma 1=\sigma 2)$, or the two population groups are homogeneous. Under this homogeneity condition, difference between sample means $(\mathrm{m} 2-\mathrm{m} 1=0.667$ approx. in Table 3$)$ is examined by $\mathrm{t}$-test statistic. The value of $\mathrm{t}$-test statistic $(\mathrm{t}=2.843$ with $\mathrm{df}=118$, in Table-02) with $\mathrm{p}$-value (in Table-03) $=$ $0.005<(\alpha=0.05)$ indicates that the two sample groups represent two significantly different populations, and hence shows that experimental group performance is better than the control group on the average. The estimated standard error of the difference between the two sample means $(\mathrm{m} 2-\mathrm{m} 1)$ is represented by se1= 0.234 (in Table 33); and 95\% Confidence Interval Limits (CIL) describe that the population mean difference $(\mu 2-\mu 1)$ is estimated to lie between the interval [0.202, 1.131].

Table 3. Independent Sample Test

\begin{tabular}{|c|c|c|c|c|c|}
\hline \multirow{3}{*}{ Independent Samples Test } & \multicolumn{5}{|c|}{ t-test for Equality of Means } \\
\hline & \multirow{2}{*}{$\begin{array}{l}\text { P-value } \\
\text { Sig. (2- } \\
\text { tailed) }\end{array}$} & \multirow{2}{*}{$\begin{array}{c}\text { Mean } \\
\text { Difference } \\
(\mathbf{m} 2-\mathbf{m} 1)\end{array}$} & \multirow[b]{2}{*}{$\begin{array}{l}\text { Std. Error } \\
\text { Difference }\end{array}$} & \multicolumn{2}{|c|}{$\begin{array}{l}95 \% \text { CIL of the } \\
\text { Difference }\end{array}$} \\
\hline & & & & Lower & Upper \\
\hline $\begin{array}{ll}\text { Pretest } & \begin{array}{l}\text { Equal variances } \\
\text { assumed }\end{array}\end{array}$ & .005 & .667 & .234 & .202 & 1.131 \\
\hline
\end{tabular}




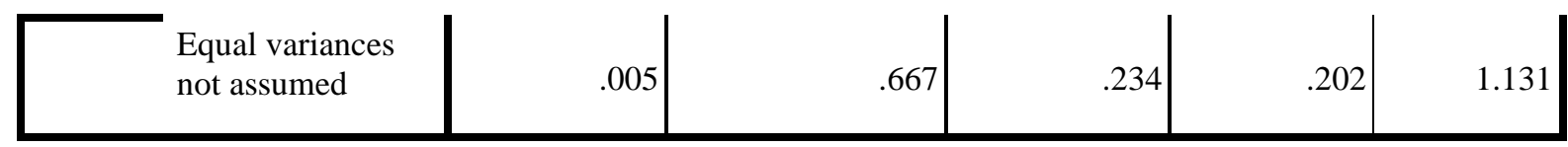

However, under non-homogeneity condition (unequal population SD, $\sigma 1 \neq \sigma 2$ ), the difference between sample means $(\mathrm{m} 2-\mathrm{m} 1=0.667$ approx. in Table 3$)$ is examined by the t-test statistic. The value of $\mathrm{t}$-test statistic $(\mathrm{t}=2.843$ with $\mathrm{df}=117.999$, in Table-02) with $\mathrm{p}$-value (in Table 3$)=0.005<(\alpha=0.05)$ also reveals the similar conclusion that the two sample groups represent two significantly different populations as Post Control and Post experimental groups, and hence shows that experimental group performance is better than the control group. The estimated standard error of the difference between the two sample means $(\mathrm{m} 2-\mathrm{m} 1)$ is represented by se $2=0.234$ (in Table-03); and 95\% CIL describe that the population mean difference $(\mu 2-\mu 1)$ is estimated to lie between the interval [0.202,1.131], similar to above one under homogeneity condition.

\section{Post Test Results}

In Table 4, the Post test results reveal that mean value $\mathrm{m} 1=11.82$ of the control gro=up is less than the mean value $\mathrm{m} 2=16.83$ of experimental group.

Table 4. Results of Independent Sample Test (Controlled as well as Experimental group)

\begin{tabular}{|l|r|r|r|r|}
\hline Posttest & \multicolumn{1}{|c|}{ N } & Mean & Std. Deviation & \multicolumn{1}{c|}{ Std. Error Mean } \\
\hline Experimental Group (x2) & 60 & 16.83 & .977 & .126 \\
control Group (x1) & 60 & 11.82 & 1.066 & .138 \\
\hline
\end{tabular}

The SD, s1 = 1.066 for control group, shows higher dispersion than of SD of experimental group s2 $=0.977$; and hence the estimated standard error for control group is se $1=0.138$ also more variability than se $2=0.126$ for experimental group.

Table 5. Independent Samples Test

\begin{tabular}{|c|c|c|c|c|}
\hline \multirow{3}{*}{ Independent Sample Test } & \multicolumn{2}{|c|}{$\begin{array}{c}\text { Levene's Test for Equality of } \\
\text { Variances } \\
\end{array}$} & \multicolumn{2}{|c|}{ t-test for Equality of Means } \\
\hline & & & & \\
\hline & $\begin{array}{l}\text { Test statistic } \\
\text { F }\end{array}$ & $\begin{array}{l}\text { p-value } \\
\text { Sig. }\end{array}$ & $\mathbf{T}$ & Df \\
\hline $\begin{array}{ll}\text { Posttest } & \text { Equal variances assumed } \\
& \text { Equal variances not assumed }\end{array}$ & .051 & .822 & $\begin{array}{l}26.879 \\
26.879\end{array}$ & $\begin{array}{r}118 \\
117.126\end{array}$ \\
\hline
\end{tabular}

In the above Table 5, the F-test statistic value $(\mathrm{F}=0.051)$ with $\mathrm{p}$-value $=0.822>(\alpha=0.05$ as level of significance) reveals that Ho is accepted and concluded that two respective populations have equal SD or variances $(\sigma 1=\sigma 2)$ or the two population groups are homogeneous. And under this homogeneity condition, the difference between sample means $(\mathrm{m} 2-\mathrm{m} 1=5.017$ approx. in Table-06) was examined by the $\mathrm{t}$-test statistic. The value of t-test statistic ( $\mathrm{t}=26.879$ with $\mathrm{df}=118$, in Table 5) with $\mathrm{p}$ - value (in Table$06)=0.000<(\alpha=0.05)$ indicates that Ho is rejected and it may be concluded that the two sample groups represent two significantly different populations and hence shows that experimental group performance is significantly much better than the control group on the average. 
The estimated standard error of the difference between the two sample means $(\mathrm{m} 2-\mathrm{m} 1)$ is represented by se $1=0.187$ (in Table 6); and 95\% CIL describes that the population mean difference $(\mu 2$ $\mu 1)$ is estimated to lie between the interval $[4.647,5.386]$, favoring that experimental group shows better performance on the average.

Table 6. Independent Sample Test

\begin{tabular}{|c|c|c|c|c|c|c|}
\hline \multirow{3}{*}{\multicolumn{2}{|c|}{ Independent Sample Test }} & \multicolumn{5}{|c|}{ t-test for Equality of Means } \\
\hline & & \multirow{2}{*}{$\begin{array}{c}\text { P-value } \\
\text { Sig. (2-tailed) }\end{array}$} & \multirow{2}{*}{$\begin{array}{l}\text { Mean Difference } \\
\quad(\mathbf{m} 2-\mathbf{m} 1)\end{array}$} & \multirow{2}{*}{$\begin{array}{l}\text { Std. Error } \\
\text { Difference }\end{array}$} & \multicolumn{2}{|c|}{$\begin{array}{l}95 \% \text { Confidence Interval } \\
\text { of the Difference }\end{array}$} \\
\hline & & & & & Lower & Upper \\
\hline \multirow[t]{2}{*}{ Pretest } & $\begin{array}{l}\text { Equal variances } \\
\text { assumed }\end{array}$ & .000 & 5.017 & .187 & 4.647 & 5.386 \\
\hline & $\begin{array}{l}\text { Equal variances } \\
\text { not assumed }\end{array}$ & .000 & 5.017 & .187 & 4.647 & 5.386 \\
\hline
\end{tabular}

However, under non-homogeneity condition (unequal population SD, $\sigma 1 \neq \sigma 2$ ), the difference between sample means $(\mathrm{m} 2-\mathrm{m} 1=5.017$ approx. in Table 6$)$ is examined by the t-test statistic. The value of $\mathrm{t}$-test statistic $(\mathrm{t}=26.879$ with $\mathrm{df}=117.126$, in Table-05) with p-value (in Table 6$)=0.000<(\alpha=0.05)$ indicates that Ho is rejected and concluded that the two sample groups represent two significantly different populations and hence shows that experimental group performance is significantly much better than the control group on the average.

The estimated standard error of the difference between the two sample means $(\mathrm{m} 2-\mathrm{m} 1)$ is represented by se $1=0.187$ (in Table 6); and 95\% CIL describes that the population mean difference $(\mu 2$ $\mu 1)$ is estimated to lie between the interval $[4.647,5.386]$, favoring that experimental group shows better performance on the average, similar to above one under homogeneity condition.

\section{Findings and Discussion}

Analysis of independent tests of controlled along with experimental group presents have presented the following findings. Looking at the tables of pre-test of both the groups it can be viewed that controlled and experimental groups do not have significant variance in their mean, standard deviation and standard error mean values. So it may be confirmed that the conventional methods have almost equal impact on both the groups. Moreover, if one looks at the results of post-test, significant variance it can be seen in the figures and results of controlled and also experimental group. The results of post-test, therefore, clearly suggest that MALL has a positive impact on the English language learning of non- formal learners. Therefore null hypothesis is rejected and the hypothesis assumed that MALL creates a positive impact is accepted.

The findings concluded from the results show remarkable resemblances with various studies conducted in the past but on different population and hypothesis. The study performed by Zhao (2005) explored the perfection of MALL for learning language. Likewise the research performed by Wang (2010) also backed up this notion that Classrooms of English language are less interested and thus make the learners low in their motivation and performance. This study is also identical with the study performed by Ali et al.,(2020) who stated that MALL impact strongly on the vocabulary learning of ESL learners. 
The outcomes also reflect similar results as the study performed by Ali, Ajmal and Anwar (2018) who showed that grammatical accuracy can be developed in ESL learners by including MALL in ESL settings. Conclusively the research also ties up with Taj el al., (2017), and also with Ahmed, Armarego and Sudweeks (2017), who concluded that positive influence of MALL on learners is undeniable The studies mentioned above also claim positive impact of MALL related to English language learning and also for vocabulary based learning

\section{Conclusion}

The results present evidence that MALL can attract learners in non-formal situations and contexts too. The introduction of MALL in non-formal settings can develop interest of local learners and it can help them to learn English language effectively. MALL can also provide motivation and confidence to learners as it did in this study. Motivated learners always have greater chance to perform better. Similar thing happened in this study with experimental group where the learners proved their progress better than the other group.

The conclusion drawn from this study also determines the fact that local Pakistani learners can be engaged in positive activities of English by utilizing MALL and by employing different MALL software. As learning English has always been a troublesome area, the utility of MALL is beneficial and can increase the efficiency of Pakistani. It can also assist the teachers in their English instructional classrooms. It can be concluded that MALL should be a permanent aspect and tool for Pakistani classrooms in non-formal settings. Furthermore MALL should be applied with proper training and knowledge to the teachers that would give best results.

\section{References}

Ali, M. M., Gulzar, M. A., \& Anwar, M. N. (2018). Impact of MALL on grammar of EFL learners in Pakistan. ELF Annual Research Journal, 20(2018), 39-55.

Ali, M. M., Khizar, N. U., Yaqub, H., Afzaal, J., \& Shahid, A. (2020). Investigating Speaking Skills Problems of Pakistani Learners in ESL Context. International Journal of Applied Linguistics and English Literature, 9(4), 62-70.

Ali, M. M., Mahmood, M. A., Anwar, M. N., Khan, L. A., \& Hussain, A. (2019). Pakistani Learners' Perceptions Regarding Mobile Assisted Language Learning in ESL Classroom. International Journal of English Linguistics, 9(4).

Ali, M. M., Yasmin, T., Kazi, A. S., Mahmood, M. A., \& Shahid, A. (2020). Evaluating the Multiple Choice Questions of Higher Secondary School English through Item

Analysis. HamdardIslamicus, 43(2.), 897-931.

Azli, W. U. A. W., Shah, P. M., \& Mohamad, M. (2018). Perception on the Usage of Mobile Assisted Language Learning (MALL) in English as a Second Language (ESL) Learning among Vocational College Students. Education, 9, 84-98.

Bajwa, N., Gujjar, A., Shaheen, G., \&Ramzan, M. (2011). A comparative study of the study habits of the students from formal and non-formal systems of education in Pakistan. International Journal of Business \& Social Science, 2(14), 175-186. 
Baloch, I., Kaye, T., Koomar, S., \&McBurnie, C. (2020). Pakistan Topic Brief: Providing Distance Learning to Hard-to-reach Children in Urban Slums and Remote Areas.(EdTech Hub Helpdesk Response No 17) DOI: 10.5281/zenodo. 3885606.

Behraam, S., Ul-Hassan, M., Perveen, S., \& Nadeem, M. (2015). Difficulties of teaching English at primary level in rural areas of Pakistan. International Journal of Information Research Review, 2(4), 646-648.

Bloch, B., Trager, G. L., \& Trager, G. L. (1942). Outline of linguistic analysis.(Special Publications of the Linguistic Society of America).

Datzberger, S. (2017). Peacebuilding through non-formal education programmes: a case study from Karamoja, Uganda. International Peacekeeping, 24(2), 326-349.

Dehkordi, M. E., \& Taki, S. (2018). Iranian Male and Female EFL Learners' Perceptions toward the Use of Mobile Assisted Language Learning. Journal of Applied Linguistics and Language Research, 5(3), 56-66.

Etling, A. (1993). What is nonformal education. Journal of agricultural education, 34(4), 72-76.

Fatima, H., \& Fatima, A. (2017). A Critically Review of Pakistan Education system compare with Iran Education system. International Journal of Social Sciences, 6(4), 233-244.

Gee, K. A. (2015). Achieving gender equality in learning outcomes: Evidence from a non-formal education program in Bangladesh. International Journal of Educational Development, 40, 207216.

Gloria, R., Tatiana, D., Constantin, R. B., \&Marinela, R. (2014). The effectiveness of non-formal education in improving the effort capacity in middle-school pupils. Procedia-Social and Behavioral Sciences, 116, 2722-2726.

Guilherme, A., \& Morgan, W. J. (2009). Martin Buber's philosophy of education and its implications for adult non-formal education. International Journal of Lifelong Education, 28(5), 565-581.

Gujjar, A. A., Naoreen, B., \& Aslam, S. (2010). A Comparative Study of the Language Learning Strategies Used by the Students of Formal and Non-Formal Systems of Education in Pakistan. Language in India, 10(5).

Harris, J., \&Wihak, C. (2018). The recognition of non-formal education in higher education: Where are we now, and are we learning from experience?. International Journal of E-Learning \& Distance Education, 33(1), 1-19.

Journal of Research and Reflections in Education June 2020, Vol.14, No 1, pp 154-170

Jumani, N. B., Rahman, F. U., \& Bibi, K. (2011). Potential of Non Formal Basic Education in Promoting Women Education in Pakistan. Online Submission, 4(1), 17-32.

Kapur, R. *2018). Curriculum and Instructional Strategies in Education retrieved from: https://files.eric.ed.gov/fulltext/EJ1245601.pdf 
Kedrayate, A. (2012). Non-formal education: Is it relevant or obsolete. International Journal of Business, Humanities and Technology, 2(4), 1-5.

Krupar, A., Horvatek, R., \& Byun, S. Y. (2017). Does nonformal education matter? Nonformal education, immigration, and skills in Canada. Adult Education Quarterly, 67(3), 186-208.

La Belle, T. J. (1982). Formal, nonformal and informal education: A holistic perspective on lifelong learning. International review of education, 28(2), 159-175.

Moayedi, A. A., \&Azizi, M. (2011). Non formal education and its relationship with bread wheat production. Procedia-Social and Behavioral Sciences, 15, 1732-1736.

Moayedi, A. A., \&Azizi, M. (2011). Non formal education and its relationship with bread wheat production. Procedia-Social and Behavioral Sciences, 15, 1732-1736.

Muhammad Mooneeb Ali1, Ahsan Bashir2*, M Asif Ikram Anjum3, Muhammad Asim Mahmood4

Norqvist, L., \&Leffler, E. (2017). Learning in non-formal education: Is it "youthful" for youth in action?. International Review of Education, 63(2), 235-256.

Oz, H. (2015). An Investigation of Preservice English Teachers' Perceptions of Mobile Assisted Language Learning. English Language Teaching, 8(2), 22-34.

Rehman, A., Jingdong, L., \& Hussain, I. (2015). The province-wise literacy rate in Pakistan and its impact on the economy. Pacific Science Review B: Humanities and Social Sciences, 1(3), 140144.

Rogers, A. (2005). Non-formal education: flexible schooling or participatory education (CERC studies in comparative education): Springer science+ Business Media, Inc./Rogers Alan. New-York, USA. Sapir, E. (1921). An introduction to the study of speech. New York: Harcourt, Brace.

Shohel, M. M. C., \& Howes, A. J. (2018). The relevance of formal and nonformal primary education in relation to health, well-being and environmental awareness: Bangladeshi pupils' perspectives in the rural contexts. International journal of qualitative studies on health and well-being, 13(1), 1554022.

Van der Linden, J. (2015). Non-formal education and new partnerships in a (post-) conflict situation:'Three cooking stones supporting one saucepan'. International Journal of Educational Development, 42, 54-62.

Yasunaga, M. (2014). Non-formal education as a means to meet learning needs of out-of-school children and adolescents. Montreal: UNESCO Institute for Statistics.

Zedan, A. M., Kadir, F. A. B. A., Yusof, M. B., Yusoff, Y. B. M., Siren, N. B. H., Mohamed, R. B., \&Toure, S. (2013). The role of language in education: Arabic as case study. Procedia-Social and Behavioral Sciences, 70, 1002-1008.

Zedan, A. M., Kadir, F. A. B. A., Yusof, M. B., Yusoff, Y. B. M., Siren, N. B. H., Mohamed, R. B., \&Toure, S. (2013). The role of language in education: Arabic as case study. Procedia-Social and Behavioral Sciences, 70, 1002-1008. 